\title{
辽河口盐地碱蓬湿地景观破碎化及驱动机制
}

\author{
曹晨晨 ${ }^{1}$, 苏芳莉 ${ }^{1,2,3}, *$, 李海福 ${ }^{1,2,3}$, 魏 超 ${ }^{1,2,3}$, 孙 迪 ${ }^{1,2,3}$ \\ 1 沈阳农业大学水利学院,沈阳 110000 \\ 2 辽宁双台河口湿地生态系统国家定位观测研究站,盘锦 124000 \\ 3 辽宁省水土流失防控与生态修复重点实验室, 沈阳 110000
}

\begin{abstract}
摘要:湿地景观破碎化的加剧严重影响了湿地生物多样性保护和湿地生态系统服务功能的维持, 本研究以辽河口盐地碱蓬 (Suaeda salsa) 湿地为研究对象,基于 GIS 平台构建 1985-2019 年间湿地景观数据库,定量分析湿地景观破碎化特征及其驱动 因素。结果表明: 1985-2019 年间,辽河口盐地碱蓬湿地呈退化趋势, 具体表现为湿地面积萎缩,湿地景观破碎化加剧。盐地 碱蓬湿地面积在 1988 年达到最大值 $4158.81 \mathrm{hm}^{2}$, 景观聚集度较高, 此后, 湿地景观破碎度出现先增大后减小再增大的波动变 化,2003 年和 2019 年盐地碱蓬湿地景观破碎化最为严重, 破碎度分别达到 5.90 和 7.89 ; 影响辽河口盐地碱蓬湿地景观破碎化 主要驱动因素为人为开发活动和水文过程; 景观破碎化的整体上升趋势与道路修建、农田开发、水产养殖、径流量和输沙量有较 好的空间对应关系,道路修建、农田开发和水产养殖面积的增加以及年径流量的减少是导致盐地碱蓬湿地景观破碎化的主导 因素。
\end{abstract}

关键词: 辽河口;盐地碱蓬湿地; 景观破碎化;驱动力

\section{Landscape fragmentation and driving mechanism of Suaeda salsa wetland in Liaohe Estuary}

\author{
CAO Chenchen ${ }^{1}$, SU Fangli ${ }^{1,2,3, *}$, LI Haifu ${ }^{1,2,3}$, WEI Chao ${ }^{1,2,3}$, SUN Di ${ }^{1,2,3}$ \\ 1 College of Water Resources, Shenyang Agricultural University, Shenyang 110000, China \\ 2 Shuangtai Estuary Wetland Ecosystem National Orientation Observation and Research Station,Panjin 124000,China \\ 3 Soil Erosion Control and Ecology in Liaoning Province Rehabilitation Key Laboratory, Shenyang 110000, China
}

\begin{abstract}
The intensification of wetland landscape fragmentation has seriously affected the protection of wetland biodiversity and the maintenance of wetland ecosystem service functions. This study took the Suaeda salsa wetland in the Liaohe River Estuary as the research object, and constructed the wetland landscape database from 1985 to 2019 based on the GIS platform, quantitative analysis of wetland landscape fragmentation characteristics and its driving factors. The results showed that from 1985 to 2019, the Suaeda salsa wetland in the Liaohe River Estuary showed a degrading trend, which was manifested in the shrinkage of wetland area and increased fragmentation of wetland landscape. The area of Suaeda salsa wetland reached its maximum of 4,158.81 hectares in 1988, and the degree of landscape aggregation was relatively high. After that, the wetland landscape fragmentation first increased, then decreased and finally increased. Suaeda salsa wetland landscape fragmentation in 2003 and 2019 was the most serious, with fragmentation degrees reaching 5.90 and 7.89, respectively; the main driving factors affecting the landscape fragmentation of Suaeda salsa wetland in the Liaohe River

基金项目: 国家重点研发计划(2016YFC0500408-9); 国家自然科学基金面上项目(31670711); 沈阳市中青年科技创新人才支持计划项目(沈阳 市湿地保护与可持续利用研究) (RC190473)

收稿日期: 2020-08-12; 网络出版日期:2021-09-10

*通讯作者 Corresponding author.E-mail: sufangli@ syau.edu.cn
\end{abstract}


Estuary were man-made development activities and hydrological processes; the overall upward trend of landscape fragmentation was related to road construction and farmland development. There was a good spatial correspondence between aquaculture, runoff and sediment transport. Road construction, farmland development, increase of aquaculture area, and reduction of runoff and sediment transport were the main factors leading to the fragmentation of the Suaeda salsa wetland landscape.

Key Words: Liaohe estuary; Suaeda salsa wetland; landscape fragmentation; driving force

景观的破碎化主要表现为斑块数量增加而面积缩小, 玟块形状趋于不规则, 斑块内部生境面积缩小, 廊道 被截断以及斑块彼此隔离 ${ }^{[1]}$, 直接影响着景观中生物多样性、能量流动、物质循环等生态特征与过程 ${ }^{[2]}$, 进而 影响物种分布 ${ }^{[3-5]}$ 。气候变化 ${ }^{[6]}$ 和人类生产活动 ${ }^{[7]}$ 等共同作用导致湿地景观破碎化, 加剧湿地退化, 严重影 响了湿地提供生物多样性保护和生态系统服务功能的维持 ${ }^{[8]}$ 。湿地退化与湿地景观破碎密切相关 ${ }^{[9-11]}$, 探 讨景观破碎的驱动机制可为湿地保护与景观修复提供科学依据 ${ }^{[12]}$ 。

辽河口盐地碱蓬湿地是著名的红海滩景观,在改良滩涂盐碱地、消减污染物和固碳增汇等方面都发挥着 重要的作用 ${ }^{[13-17]}$ 。该区域也是全球最大的黑嘴鸥栖息地,在保护区域生态安全及维系生物多样性方面发挥 着不可替代的生态作用。盐地碱蓬湿地广泛分布于辽河口潮间带 ${ }^{[18-19]}$, 地处陆地和海洋交汇区域,其景观完 整受到气候变化、海平面上升及人类活动等多重作用,驱动机制复杂 ${ }^{[20]}$ 。

基于遥感和 GIS 手段结合景观生态学等方法对湿地景观展开研究,有利于从宏观角度明确湿地景观格局 及其变化规律 ${ }^{[21-23]}$, 但常存在时间序列较短、时间步长较长, 难以揭示快速变化的湿地景观演变特征及规律 等问题。本研究以 Landsat 卫星 1985-2019 年间共 27 期影像为数据源, 通过主成分分析和相关分析研究其 驱动机制, 可在较长时间段序列内、较精准揭示辽河口盐地碱蓬湿地景观格局及其演变规律。

\section{1 研究区概况}

辽河口湿地属于滨海湿地, 位于我国渤海辽东湾北部顶端 (图 1), 辽河人海口处 $\left(121^{\circ} 30^{\prime}-122^{\circ} 00^{\prime} \mathrm{E}\right.$, $\left.40^{\circ} 50^{\prime}-41^{\circ} 20^{\prime} \mathrm{N}\right)$ 。属温带半湿润季风气候, 年平均降雨量 $650 \mathrm{~mm}$, 年平均温度 $8.5^{\circ} \mathrm{C}$ 。1 988 年, 双台子河 口 (现更名为辽河口) 被列入国家级自然保护区, 总面积 8 万 $\mathrm{hm}^{2}$, 距海较近的裸滩区域没有植物生长, 过渡带

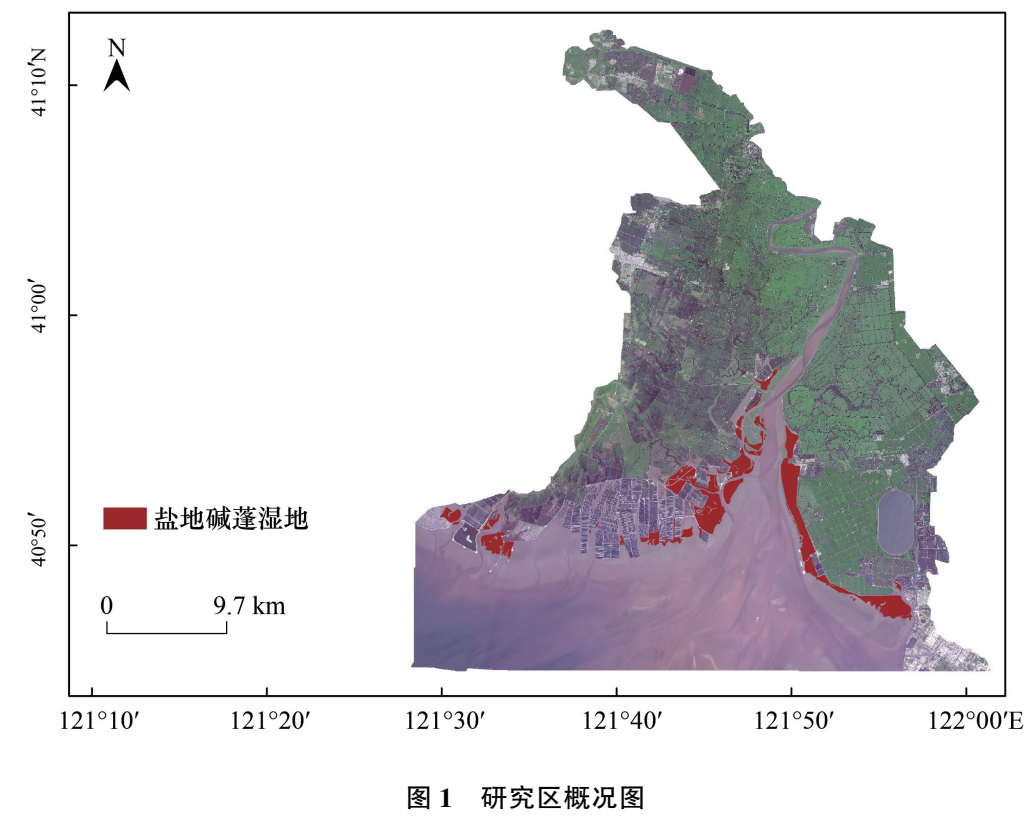

Fig.1 Overview of the study area 
为盐地碱蓬湿地和距海较远的区域为内陆芦苇湿地, 是一个以保护丹顶鹤、黑嘴鸥等珍稀水禽及滨海湿地生 态系统为主的野生动物类型自然保护区。其中盐地碱蓬湿地分布于潮间带, 介于芦苇湿地与潮滩之间, 呈红 紫色的不规则斑块。

\section{2 数据来源及研究方法}

\section{1 遥感影像数据}

本研究使用的 Landsat 系列遥感数据来源于美国地质勘探局 USG 网站 (https://glovis.usgs.gov/app)。

为能够更加全面且真实的探究辽河口盐地碱蓬湿地时空动态的变化特征及规律, 根据辽河口区域开发建 设节点以及遥感影像的质量, 选取 1985 年和 1988 年(防潮大堤修建前)、1989 年 (防潮大堤修建) 、19921997 年( 防潮大堤修建后)、1999-2004 年(农田开怎及水产养殖建设期)、2005-2007 年和 2009-2014 年 (湿地相关法律法规逐步完善)、2015 年、2017 年和 2019 年(近 5 年湿地状况) 共计 27 期的遥感影像为数据 源, 云层低于 $10 \%$, 时相为 9-10 月份, 质量较好, 条带号为 120/032, 卫星影像的误差小于一个像素 (空间分 辨率为 $30 \mathrm{~m}$ )。

遥感影像在获取过程中, 大气对阳光和来自目标的辐射会产生吸收和散射, 图像可能存在一定程度的失 真。使用 ENVI 软件的 FLAASH 模块 (大气校正模块) 进行大气校正部分的工作。再对所有的 Landsat 图像在 同一投影坐标系统中 (UTM 投影, WGS84 参考系统) 进行了测量和几何校正,使得所有影像的配准误差均在 一个像素内 (小于 $30 \mathrm{~m}$ )。通过 ArcGIS 平台的掩膜提取工具, 将遥感影像裁剪至辽河口国家湿地自然保护区 形状。目视解译完成后根据 Google Earth 当前和历史影像资料和实地考察数据, 采用总体精度指标对盐地碱 蓬湿地的目视解译精度进行验证, 其总体精度为 $85.62 \%$ 。

总体精度 $O A$ 的计算公式为

$$
O A=\frac{1}{n} \sum_{k=1}^{N} a_{k k}
$$

式中, $O A$ 是总体精度,表示所有像元分类的正确性, $N$ 为样点总数, $a_{k k}$ 表示 $k$ 行 $k$ 列上的值。

\section{2 水文数据}

本研究使用的水文数据来《辽宁省水文统计年鉴》1985-2017 年的数据, 由于辽河口盐地碱蓬湿地主要 受河海交互作用影响, 因此选取辽河人海口前最后一个水文站一一六间房水文站数据, 指标选取了表征上游 降雨和径流输沙过程的降雨量、径流量及输沙量。

2.3 景观破碎化指数

本研究选取斑块密度 $(P D)$ 作为描述景观破碎度的指标, $P D$ 值越大代表景观破碎化程度越高。

$$
P D=\frac{N_{i}}{A}
$$

式中, $N_{i}$ 为景观中第 $i$ 类景观要素的总面积, $A$ 为景观总面积。

具体景观指数分析计算在 FRAGSTATS 4.2 软件中完成。

\section{4 潮汐作用指标}

辽河口盐地碱蓬湿地位于海洋与陆地之间的过渡地带, 其临近海洋的一侧为平均宽度约为 $4 \mathrm{~km}$ 的潮间 带, 潮汐经过宽阔的潮滩经潮沟作用于盐地碱蓬湿地。其独特的地理位置, 使得波浪和潮汐作用极其复杂。 前期研究中已明确了海岸线的变迁和潮滩区的淤积侵蚀速率与潮汐运动相关 ${ }^{[24-25]}$, 可表征潮汐作用。

2.5 湿地景观破碎化驱动机制分析

根据相关文献 ${ }^{[26-28]}$ 及辽河口盐地碱蓬湿地实际情况, 选取道路、水库、田地、养殖、油井、降雨量、径流量、 输沙量净岸线运动和淤积侵蚀速率因子。通过主成分分析进行指标的降维确定主要指标, 通过灰色关联度分 析各驱动因素对湿地景观破碎化的影响权重,采用相关分析法分析各驱动因素对于湿地景观破碎化的影响。 


\section{3 结果与分析}

3.1 辽河口盐地碱蓬湿地景观破碎化特征

斑块密度 $(P D)$ 作为描述景观破碎度的重要指标, $P D$ 值越大代表景观破碎化程度越高。由图 2 可见， 1985-1988 年盐地碱蓬湿地表现出显著的聚集性, $P D$ 值由 1985 年的 4.68 减少为 1988 年的 1.06 , 减少了 77.35\% ; 1989-1995 年盐地碱蓬湿地破碎化特征初现， $P D$ 值由 1989 年的 1.12 增加为 1995 年的 3.33 , 增加了 $197.32 \%$; 1996 年盐地碱蓬湿地破碎化程度得到一定程 度减缓, $P D$ 值由 1995 年的 3.33 减少为 1996 年的1.55, 减少了 $53.45 \%$; 1997-2003 年盐地碱蓬湿地破碎化程 度波动加剧, $P D$ 值由 1997 年的 1.88 增加为 2003 年的 5.90 , 增加了 $213.83 \%$; 2004-2014 年盐地碱蓬湿地破 碎化程度波动减缓, 由 2005 年的 5.90 减少为 2014 年 的 2.74 , 减少了 $53.56 \%$; 2015 年至今, 盐地碱蓬湿地破 碎化加剧, $P D$ 值由 2014 年的 2.74 增加为 2019 年的

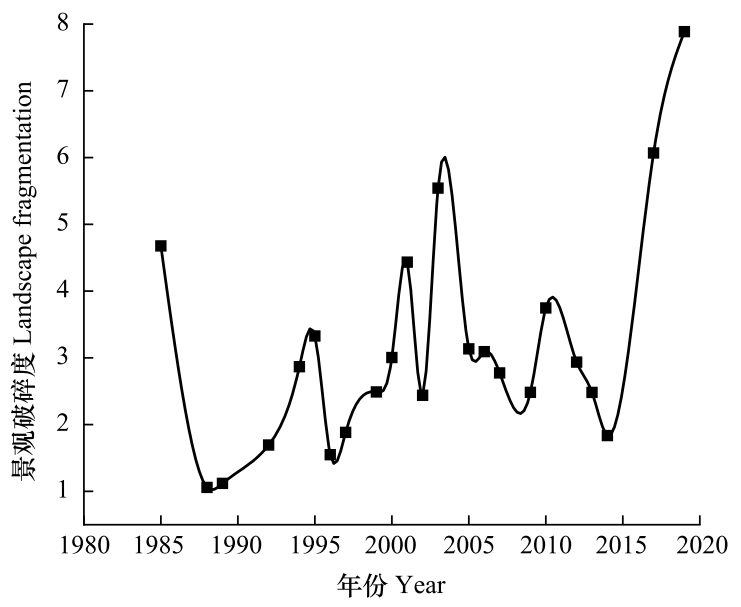

图 $21985-2019$ 年盐地碱蓬湿地 $P D$ 值变化

Fig.2 Changes in $P D$ value of Suaeda salsa wetland from 1985 to 2019 7.89 , 增加了 $187.96 \%$ 。

1985-2019 年辽河口盐地碱蓬湿地的 $P D$ 值总体上呈上升趋势, 说明近 35 年来辽河口盐地碱蓬湿地景 观破碎程度存在阶段性波动但从长时间序列上看仍长期处于破碎化状态,其中, 2003 年和 2017 年辽河口盐 地碱蓬湿地景观破碎化极为严重。

3.2 辽河口盐地碱蓬湿地景观破碎化驱动机制分析

\subsection{1 指标选取与评价}

湿地景观破碎化主要受人为因素和自然因素的影响,其中油田开采、海产养殖等围填海人为开发工程是 造成湿地景观破碎化的主要驱动因子 ${ }^{[29]}$ 。在辽河口区域内, 主要的围填海工程包括道路修建、水库修建、农 田开发、水产养殖和油田开发; 盐地碱蓬湿地由于其处于海陆交汇处的特殊分布位置,主要的自然因素包括气 候因素、内陆河流作用因素以及海洋波浪潮汐作用因素 ${ }^{[6]}$ 。

本研究选取表征景观破碎化程度的指标斑块密度 $(P D)$ 作为因变量 $Y$,选取与湿地景观破碎化显著相关 的驱动因子道路 $\left(X_{1}\right)$ 、水库 $\left(X_{2}\right)$ 、农田 $\left(X_{3}\right)$ 、养殖 $\left(X_{4}\right)$ 、油井 $\left(X_{5}\right)$ 、降雨量 $\left(X_{6}\right)$ 、径流量 $\left(X_{7}\right)$ 、输沙量 $\left(X_{8}\right)$ 、 净岸线运动 $\operatorname{NSM}\left(X_{9}\right)$ 、淤积侵蚀速率 $\left(X_{10}\right)$ 作为自变量,进行主成分分析。

自变量相关系数矩阵显示 (表 1), 影响景观破碎化的 10 个自变量中存在着不同程度的相关性,表明各自 变量包含信息存在重叠,运用主成分分析是必要的。对自变量进行 KMO 统计量检验和 Bartlett 球形检验显 示: KMO 统计量达到 0.525 , Bartlett's 球形检验显著性水平小于 0.01 ,适合进行主成分分析。

\section{2 .2 主成分分析}

主成分分析结果显示 (表 2),第 1 主成分的特征值为 3.931 ,第 2 主成分的特征值为 2.031 ,第 3 主成分的 特征值为 1.557 , 累积贡献率为 $75.187 \%$, 说明 3 个主成分已能代表原始驱动因子来反映辽河口盐地碱蓬湿地 景观破碎化的具体情况。

由表 3 可知,在第一主成分在输沙量和径流量上的因子荷载量较大,分别为 0.889 、和 0.856 ;第二主成分 在淤积侵蚀速率、净岸线运动、水产养殖、水库修建和油井开发上的因子荷载量较大, 分别为 $0.736 、 0.633$ 、 $0.569 、 0.504$ 和 0.436 ; 第三主成分明显与海岸线淤积侵蚀级水产养殖相关, 显然未能与第二主成分区分开来, 需进一步进行因子分析,使结果进一步优化,使提取信息含义更加清晰。 
表 1 自变量相关系数矩阵

Table 1 Correlation coefficient matrix of independent variables

\begin{tabular}{|c|c|c|c|c|c|c|c|c|c|c|}
\hline & $X_{1}$ & $X_{2}$ & $X_{3}$ & $X_{4}$ & $X_{5}$ & $X_{6}$ & $X_{7}$ & $X_{8}$ & $X_{9}$ & $X_{10}$ \\
\hline$X_{1}$ & 1 & & & & & & & & & \\
\hline$X_{2}$ & $0.903^{* * * *}$ & 1 & & & & & & & & \\
\hline$X_{3}$ & $0.562^{\text {*** }}$ & $0.753^{\text {***** }}$ & 1 & & & & & & & \\
\hline$X_{4}$ & $-0.644^{* * *}$ & $-0.455^{*}$ & -0.221 & 1 & & & & & & \\
\hline$X_{5}$ & $-0.384^{*}$ & $-0.373^{*}$ & -0.168 & $0.541^{* *}$ & 1 & & & & & \\
\hline$X_{6}$ & $-0.422 *$ & $-0.437^{*}$ & $-0.349^{*}$ & $0.402 *$ & $0.456^{*}$ & 1 & & & & \\
\hline$X_{7}$ & $-0.315^{*}$ & -0.048 & 0.182 & $0.641^{* * * *}$ & $0.595^{* * * *}$ & 0.221 & 1 & & & \\
\hline$X_{8}$ & -0.480 ** & $-0.447^{*}$ & $-0.341 *$ & 0.344 * & -0.016 & $0.417^{*}$ & -0.052 & 1 & & \\
\hline$X_{9}$ & -0.194 & $-0.273^{*}$ & -0.172 & 0.116 & 0.088 & $0.280^{*}$ & 0.123 & $0.372^{*}$ & 1 & \\
\hline$X_{10}$ & 0.11 & -0.004 & -0.028 & -0.135 & -0.204 & $-0.305^{*}$ & -0.067 & 0.137 & $0.740^{* * * *}$ & 1 \\
\hline
\end{tabular}

$X_{1}$ 道路面积 Road area; $X_{2}$ 水库面积 Reservoir area; $X_{3}$ 农田面积 Farmland area; $X_{4}$ 养殖面积 Breeding area; $X_{5}$ 油井面积 Oil well area; $X_{6}$ 年降雨 量 Annual rainfall; $X_{7}$ 年径流量 Annual runoff; $X_{8}$ 年输沙量 Annual sediment transport; $X_{9}$ 净岸线运动 Net shoreline movement; $X_{10}$ 淤积侵蚀速率 Siltation erosion rate

表 2 主成分特征值和贡献率

Table 2 Principal component eigenvalues and contribution rate

\begin{tabular}{|c|c|c|c|c|c|c|}
\hline \multirow{2}{*}{$\begin{array}{l}\text { 成分 } \\
\text { Ingredients }\end{array}$} & \multicolumn{3}{|c|}{$\begin{array}{c}\text { 初始特征值 } \\
\text { Initial eigenvalue }\end{array}$} & \multicolumn{3}{|c|}{$\begin{array}{l}\text { 提取平方和载人 } \\
\text { Extract the sum of squares and load }\end{array}$} \\
\hline & $\begin{array}{l}\text { 合计 } \\
\text { Total }\end{array}$ & $\begin{array}{l}\text { 方差的 } / \% \\
\text { Variance } / \%\end{array}$ & $\begin{array}{c}\text { 累积 } / \% \\
\text { Cumulative/\% }\end{array}$ & $\begin{array}{l}\text { 合计 } \\
\text { Total }\end{array}$ & $\begin{array}{l}\text { 方差的 } / \% \\
\text { Variance } / \%\end{array}$ & $\begin{array}{c}\text { 累积 } \% \\
\text { Cumulative/\% }\end{array}$ \\
\hline 输沙量 Annual sediment transport & 3.931 & 39.309 & 39.309 & 3.931 & 39.309 & 39.309 \\
\hline 径流量 Annual runoff & 2.031 & 20.310 & 59.620 & 2.031 & 20.310 & 59.620 \\
\hline 降雨量 Annual rainfall & 1.557 & 15.567 & 75.187 & 1.557 & 15.567 & 75.187 \\
\hline 道路 Road area & 0.856 & 8.562 & 83.749 & & & \\
\hline 水库 Reservoir area & 0.743 & 7.430 & 91.179 & & & \\
\hline 农田 Farmland area & 0.311 & 3.113 & 94.292 & & & \\
\hline 养殖 Breeding area & 0.294 & 2.942 & 97.234 & & & \\
\hline 油井 Oil well area & 0.191 & 1.906 & 99.140 & & & \\
\hline NSM Net shoreline movement & 0.066 & 0.660 & 99.799 & & & \\
\hline 淤积侵蚀速率 Siltation erosion rate & 0.020 & 0.201 & 100.000 & & & \\
\hline
\end{tabular}

表 3 主成分荷载矩阵

Table 3 Principal component load matrix

\begin{tabular}{|c|c|c|c|}
\hline \multirow{2}{*}{$\begin{array}{l}\text { 影响因子 } \\
\text { Impact factor }\end{array}$} & \multicolumn{3}{|c|}{ 成分 Ingredients } \\
\hline & 1 & 2 & 3 \\
\hline 输沙量 Annual sediment transport & -0.889 & 0.025 & 0.159 \\
\hline 径流量 Annual runoff & -0.856 & 0.237 & 0.283 \\
\hline 降雨量 Annual rainfall & -0.623 & 0.363 & 0.457 \\
\hline 道路 Road area & 0.754 & 0.344 & 0.237 \\
\hline 水库 Reservoir area & 0.602 & 0.504 & 0.260 \\
\hline 农田 Farmland area & 0.680 & 0.115 & -0.085 \\
\hline 养殖 Breeding area & 0.416 & 0.569 & 0.617 \\
\hline 油井 Oil well area & 0.565 & -0.436 & -0.077 \\
\hline 净岸线运动 Net shoreline movement & 0.361 & -0.633 & 0.600 \\
\hline 淤积侵蚀速率 Siltation erosion rate & -0.066 & -0.736 & 0.604 \\
\hline
\end{tabular}

\subsection{3 因子分析}

为更好的将盐地碱蓬湿地演变驱动因子与主成分之间的线性关系表现出来,选取第 1 主成分、第 2 主成 分和第 3 主成分作为新的变量,建立单个主成分综合得分线性方程,其系数为主成分特征值所对应的特征向 
量,由各因子在主成分上的载荷与特征值计算得出,得到式(1)、式(2)和式(3)。

$$
\begin{aligned}
& F_{1}=-0.448 X_{1}-0.431 X_{2}-0.314 X_{3}+0.380 X_{4}+0.304 X_{5}+0.343 X_{6}+0.210 X_{7}+0.285 X_{8}+0.182 X_{9}-0.033 X_{10} \\
& F_{2}=0.018 X_{1}+0.167 X_{2}+0.255 X_{3}+0.242 X_{4}+0.354 X_{5}+0.080 X_{6}+0.399 X_{7}-0.306 X_{8}-0.444 X_{9}-0.516 X_{10} \\
& F_{3}=0.126 X_{1}+0.225 X_{2}+0.364 X_{3}+0.188 X_{4}+0.207 X_{5}-0.068 X_{6}+0.492 X_{7}-0.061 X_{8}+0.478 X_{9}+0.481 X_{10}
\end{aligned}
$$

得到各驱动因子与主成分的线性方程后,进一步建立辽河口盐地碱蓬湿地演变驱动因子综合得分模型, 见式(4), 该式的系数即为第 1 主成分 $F_{1}$ 、第 2 主成分 $F_{2}$ 和第 3 主成分 $F_{3}$ 各自所对应的方差贡献率与累积贡 献率之比。

$$
\begin{aligned}
Y= & 0.198 F_{1}+1.425 F_{2}+1.256 F_{3}=-0.203 X_{1}-0.133 X_{2}-0.019 X_{3}+0.303 X_{4}+0.297 X_{5}+0.186 X_{6}+0.320 X_{7}+ \\
& 0.053 X_{8}+0.075 X_{9}-0.056 X_{10}
\end{aligned}
$$

式中, 各系数分别为各驱动因子在综合得分中的权重, 系数越大则说明该因子在综合得分中占据的重要性越 大,通过该式可进一步确定,辽河口盐地碱蓬湿地景观破碎化的主要驱动因子为水产养殖 $(0.320)$ 、道路修建 (0.303)、水库修建 $(0.297)$ 、年输沙量 $(0.203)$ 、农田开发 $(0.186)$ 以及年径流量 $(0.133)$ 。

\subsection{4 湿地景观破碎化驱动力分析}

通过主成分分析确定水产养殖、道路修建、水库修建、年输沙量、农田开发和年径流量为导致湿地景观破 碎化的主要驱动力,因此,选择以上因子为比较数列,通过灰色关联度和相关性分析探究其驱动机制。

\begin{tabular}{|c|c|c|c|c|c|c|}
\hline 关联矩阵 & 养殖 & 道路 & 水库 & 年输沙量 & 农田 & 年径流量 \\
\hline $\begin{array}{l}\text { Incidence } \\
\text { matrix }\end{array}$ & $\begin{array}{l}\text { Breeding } \\
\text { area }\end{array}$ & $\begin{array}{c}\text { Road } \\
\text { area }\end{array}$ & $\begin{array}{c}\text { Reservoir } \\
\text { area }\end{array}$ & $\begin{array}{c}\text { Annual sediment } \\
\text { transport }\end{array}$ & $\begin{array}{c}\text { Farmland } \\
\text { area }\end{array}$ & $\begin{array}{c}\text { Annual } \\
\text { runoff }\end{array}$ \\
\hline$P D$ & 0.4729 & 0.4789 & 0.2879 & 0.286 & 0.3497 & 0.354 \\
\hline
\end{tabular}

通过灰色关联度分析 (表 4) 可知,道路修建是影响盐地碱蓬湿地景观破碎化的主要驱动因子,其次是水 产养殖、年径流量和农田开发。

表 4 灰色关联矩阵

Table 4 Grey incidence matrix

$P D$ : 斑块密度 Patch density

(1) 人为因素对湿地景观破碎化的驱动

人类活动对辽河口盐地碱蓬湿地景观破碎化的影响主要体现在农田开发、道路修建和水产养殖方面。 1985-2019 年期间辽河口区域道路修建、水产养殖和农田开发面积逐年递增且趋于稳定, 与盐地碱蓬湿地景 观破碎化增强的趋势呈指数相关( 图 3-图 5 ), $R^{2}$ 分别 为 $0.340 、 0.281$ 和 0.460 。

道路修建直接破坏了辽河口区域河网水系及盐地 碱蓬湿地斑块之间的连通性,不利于盐地碱蓬湿地斑块 之间物质、能量的传递, 导致湿地自净能力和纳污能力 的减弱, 造成盐地碱蓬湿地景观破碎化加剧。19852019 年间辽河口区域道路修建面积呈对数增长 (图 3, $P<0.05), 2003$ 年出现阶段性的面积峰值 $967.36 \mathrm{hm}^{2}$, 并于 2017 年达到最大值 $1045.43 \mathrm{hm}^{2}$ 。

水产养殖通过土地占用的形式直接侵占盐地碱蓬的 生长空间,此外水产养殖行业日常生产的污染物通过海 水交换形式被带到潮间带区域,造成水质污染 ${ }^{[30]}$, 导致 盐地碱蓬湿地景观破碎化加剧。1985-2019 年间辽河口 区域水产养殖面积呈对数增长 ( 图 4, $P<0.05$ ), 并于 2017

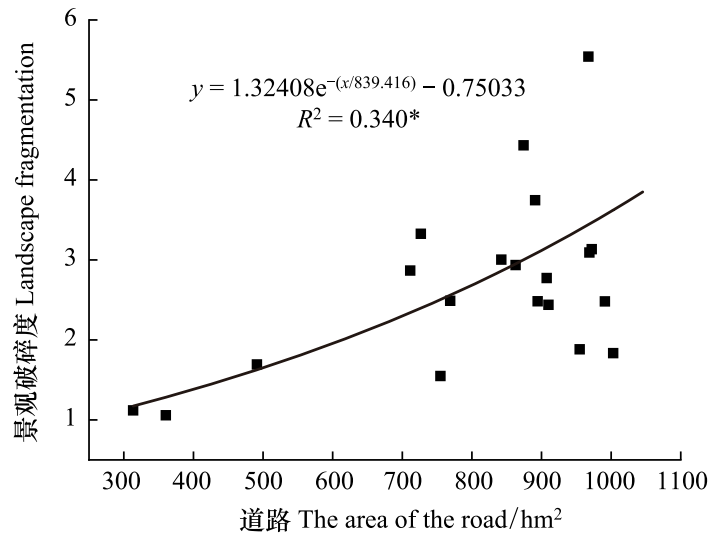

图 3 景观破碎度与道路修建的关系

Fig.3 The relationship between landscape fragmentation and road construction

*表示显著相关 $(P<0.05)$ 年达到水产养殖面积最大值 $9244.73 \mathrm{hm}^{2}$, 同年辽河口盐 
地碱蓬湿地景观破碎化剧烈, $P D$ 值高达 6.07 。

农田开发通过长时间的种稻灌溉, 降低土壤盐分含量, 改变土壤盐分组成 ${ }^{[31]}$, 导致辽河口区域土壤脱盐, 土壤盐分过低不利于盐地碱蓬生长, 造成盐地碱蓬湿地景观破碎化加剧。1985-2019 年间辽河口区域农田 开发面积呈对数增长 (图 5,P<0.05), 并于 2003 年达到农田开发面积最大值 $5479 \mathrm{hm}^{2}$, 同年辽河口盐地碱蓬 湿地景观破碎化剧烈, $P D$ 值高达 5.90。

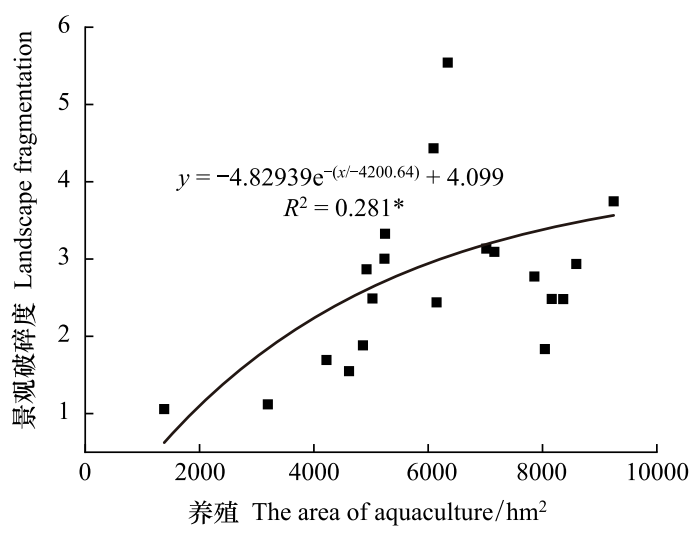

图 4 景观破碎度与水产养殖的关系

Fig.4 The relationship between landscape fragmentation and aquaculture

*表示显著相关 $(P<0.05)$

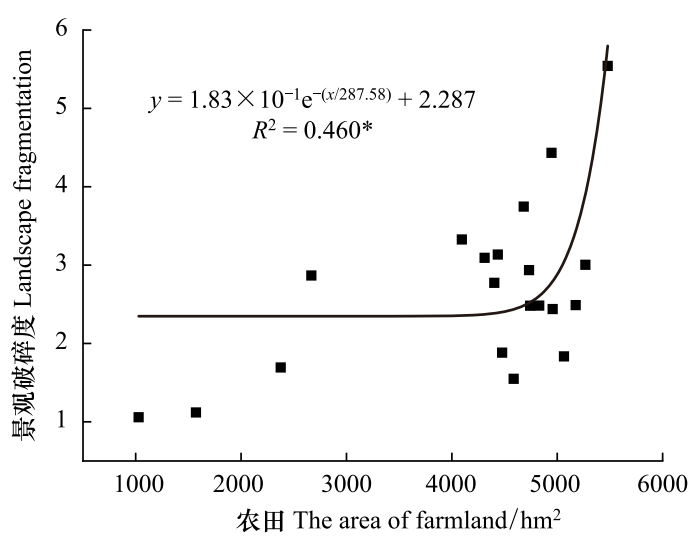

图 5 景观破碎度与农田开发的关系

Fig.5 The relationship between landscape fragmentation and farmland development

*表示显著相关 $(P<0.05)$

近 35 年间,辽河口盐地碱蓬湿地向退化方向发展, 具体表现为湿地面积萎缩, 湿地景观破碎化加剧。 2003 年后, 围填海工程面积趋于稳定, 人为开发活动对盐地碱蓬湿地景观破碎化的影响趋于稳定, 但是湿地 景观破碎化随农田开发、道路修建和水产养殖面积的增大而增大的整体趋势是明确的。

(2) 水文过程对湿地景观破碎化的驱动

水文过程对辽河口盐地碱蓬湿地景观破碎化的影响主要体现在径流方面。1985-2019 年间,六间房水 文站年径流量与盐地碱蓬湿地景观破碎化呈负相关, 其线性拟合优度为 $0.775(P<0.01)$ (图 6), 湿地景观破 碎化随径流量增大而减小。

由图 7 可见, 1985-2019 年 35 年的径流量距平百分率发现辽河枯水年与盐地碱蓬湿地景观破碎化严重 年份重合, 丰水年时期的盐地碱蓬长势明显好于枯水年时期的盐地碱蓬的情况, 且盐地碱蓬湿地景观破碎化 的年际变化趋势与辽河干流的年径流量变化趋势大致相同。

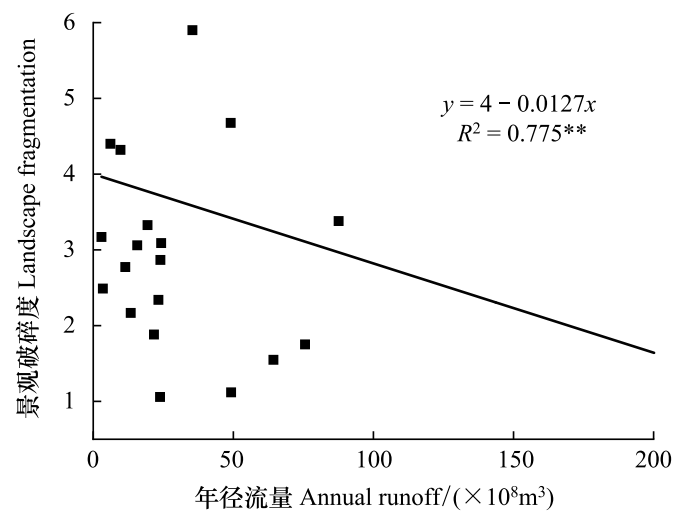

图 6 景观破碎度与径流量的关系

Fig.6 The relationship between landscape fragmentation and runoff

** 表示极显著相关 $(P<0.01)$

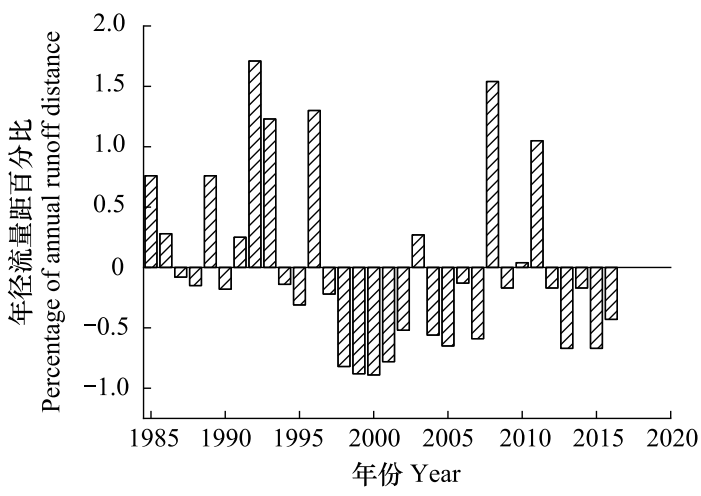

图 71985 - 2019 年辽河口区域年径流量距百分比率

Fig. 7 Percentage rate of annual runoff distance in Liaohe Estuary from 1985 to 2019 
1998 年上游流向海水的水沙骤减,年径流量分别减少了 $24.95\left(10^{8} / \mathrm{m}^{3}\right)$, 其原因是大洼三角洲平原水库 修建完成后开始对上游的淡水进行储蓄,改变了辽河口区域的水文条件,打破了原有的湿地生态系统平衡, 对 盐地碱蓬的生长造成了巨大的影响, 导致盐地碱蓬湿地景观破碎化加剧, 盐地碱蓬湿地斑块密度 $(P D)$ 由 1988 年的 1.058 增长为 1998 年的 2.49 。

\section{4 讨论}

(1) 解译 1985-2019 年间 27 期 Landsat 数据, 可较准确揭示辽河口盐地碱蓬湿地景观破碎化特征, 较好 的解决了以往研究中存在的时间序列较短、时间步长较大的问题 ${ }^{[28,32]}$, 黄河三角洲的相关研究 ${ }^{[33]}$ 表明,进一 步增加总体样品数量, 可较好的揭示景观格局演变规律。故建议利用超过 20 年的数据进行景观破碎特征 研究。

（2）1985-2019 年间, 辽河口盐地碱蓬湿地滨海湿地呈退化趋势, 具体表现为湿地面积萎缩, 湿地景观破 碎化加剧。1988 年为盐地碱蓬湿地景观完整性最佳的年份, 湿地面积大且景观聚集性高, 此时的辽河口区域 原始生态系统保存较好; 自 1990 年始,辽河口区域进人经济发展的新阶段,由盘锦市统计年鉴显示 1990 年的 第一、二、三产业产值相比 1985 年分别增长 $144.87 \% 、 83.61 \% 、 340.32 \%$, 农田开发、水产养殖、油气开采、旅游 服务等各项产业快速发展的同时, 也为生态系统带来了巨大的压力, 大量人为扰动占地涌人辽河口区域, 导致 1990-2003 年间盐地碱蓬湿地一直处于破碎化持续加剧的状态; 粗狂无序的开发利用模式所导致的生态环 境问题逐渐被人们所察觉,2004 年国务院办公厅发布了《关于加强湿地保护管理的通知》,各地方积极响应出 台一系列湿地保护与修复政策, 辽河口盐地碱蓬湿地破碎化趋势也得到缓解;2015 年至今, 由于淡水资源的 贯乏,径流量减少,盐导致地碱蓬湿景观破碎化再度加剧。

(3) 导致辽河口盐地碱蓬湿地景观破碎化加剧的人为驱动因素为道路、农田和养殖, 其中, 道路修建直接 破坏了辽河口区域河网水系及盐地碱蓬湿地斑块之间的连通性,降低了湿地的污染自净能力; 农田围垦和围 海养殖在造成盐地碱蓬湿地原位生境被替代的同时, 其日常产生的的污染物通过海水交换形式导致近岸水质 与底泥环境污染加剧,生态环境遭到严重破坏,盐地碱蓬湿地景观破碎化加剧 ${ }^{\left[{ }^{[0]}\right.}$ 。

(4) 导致辽河口盐地碱蓬湿地景观破碎化加剧的水文驱动因素为年径流量, 盐地碱蓬湿地因其独特的地 理位置, 区域水分盐度由河水和海水的彼消此长决定, 上游径流量的减少引起海水倒灌, 加剧了盐地碱蓬湿地 的景观破碎化程度。

\section{5 结论}

1985-2019 年间,辽河口盐地碱蓬湿地呈退化趋势, 具体表现为湿地面积萎缩,湿地景观破碎化加剧。 道路修建、农田开发和水产养殖面积的增加以及年径流量的减少是导致盐地碱蓬湿地景观破碎化的主导 因素。

\section{参考文献 (References) :}

[ 1 ] 唐建, 谭飞, 周琳. 景观破碎化对物种多样性的影响探讨. 绿色科技, 2018, (24): 158-161.

[ 2 ] 巫丽芸, 何东进, 游巍斌, 纪志荣, 黄昕宇. 东山岛海岸带景观破碎化时空梯度分析. 生态学报, 2020, 40(3): 1055-1064.

[ 3 ] Keshtkar H, Voigt W. Potential impacts of climate and landscape fragmentation changes on plant distributions: coupling multi-temporal satellite imagery with GIS-based cellular automata model. Ecological Informatics, 2016, 32: 145-155.

[ 4 ] Mitchell M G E, Suarez-Castro A F, Martinez-Harms M, Maron M, McAlpine C, Gaston K J, Johansen K, Rhodes J R. Reframing landscape fragmentation's effects on ecosystem services. Trends in Ecology \& Evolution, 2015, 30(4) : 190-198.

[ 5 ] Puzin C, Pétillon J. Contrasted responses of dominant ground-dwelling arthropods to landscape salt-marsh fragmentation. Estuarine, Coastal and Shelf Science, 2019, 224: 138-141.

[ 6 ] 孙砳石, 柏林, 刘艳, 刘志欣, 关宁欣. 气候变化对扎龙湿地景观破碎化过程的影响. 湿地科学与管理, 2018, 14(3): 40-44.

[ 7 ] 胡娟, 马安青, 马冰然. 2000-2014 年子牙河流域湿地景观格局演变及驱动力分析. 中国海洋大学学报, 2017, 47(9)：110-118. 
[ 8 ] Adade R, Nyarko B K, Aheto D W, Osei K N. Fragmentation of wetlands in the south eastern coastal savanna of Ghana. Regional Studies in Marine Science, 2017, $12: 40-48$.

[ 9 ] 徐晓然, 谢跟踪, 邱彭华. 1964-2015 年海南省八门湾红树林湿地及其周边土地景观动态分析. 生态学报, 2018, 38(20): 7458-7468.

[10] YuhaiBao, SuyaBao, Yinshan. Analysis on temporal and spatial changes of landscape pattern in dalinor lake wetland. Procedia Environmental Sciences, 2011, 10: 2367-2375.

[11] 赵锐锋, 姜朋辉, 赵海莉, 㚞洁平. 黑河中游湿地景观破碎化过程及其驱动力分析. 生态学报, 2013, 33(14): 4436-4449.

[12] 高跃鹏, 张学霞, 方宇, 张雪, 郭建斌. 若尔盖县景观破碎化及湿地恢复优先性. 中国农业大学学报, 2019, 24(12): 145-158.

[13] 袁晓敏, 杨继松, 刘凯, 郑冬梅, 郑佳玉, 刘强. 辽河口滨海湿地 $\mathrm{CH}_{4}$ 排放特征及其影响因素. 生态学报, 2019, 39(5): 1829-1837.

[14] 刘欢. 翅碱蓬根系分泌物对细菌去除 Cd 作用的影响 [D]. 大连: 大连海洋大学, 2019.

[15] 余雪洋, 叶思源, Yuknis N L, Law E A, 赵广明, 袁红明, 丁喜桂, 王锦. 辽河三角洲翅碱蓬湿地不同植被覆盖度下的土壤对碳的扣留. 中国地质, 2014, 41(2): 648-657.

[16] 国艳春, 王思零, 曾路生, 初庆刚, 王胜. 翅碱蓬施用不同肥料对滨海盐碱地土壤理化性质、酶活性及团聚性的影响. 山东农业科学, $2020,52(1): 76-81$.

[17] 赵肖依, 魏海峰, 黄欣, 何洁, 张明亮. 不同水位条件对翅碱蓬发芽与生长的影响. 环境生态学, 2019, 1(6): 18-22.

[18］曹晟阳, 谢欠影, 伊凯, 刘璐. 翅碱蓬耐盐机制研究进展. 现代农业科技, 2018, (5): 169-171, 174-174.

[19］杨楚烨, 王立, 苏芳莉, 李海福. 辽河口湿地翅碱蓬群落及其交错区土壤盐分特征. 中国水土保持科学, 2019, 17(1): 117-123.

[20］苏芳莉, 宋飞, 董琳琳, 李海福, 王铁良. 辽河口潮间带景观破碎度演变驱动因素. 沈阳农业大学学报, 2020, 51(2): 199-205.

[21］苏凯，王茵然，孙小婷，岳德鹏. 基于 GIS 与 RS 的东北森林带景观格局演变与模拟预测. 农业机械学报, 2019, 50(12) : 195-204.

[22] 刘康, 间家国, 邹雨璇, 宋国香, 郑京晶, 崔保山. 黄河三角洲盐地碱蓬盐沼的时空分布动态. 湿地科学, 2015, 13(6) : 696-701.

[23] 路春燕, 高式斌, 陈远丽, 贾明明, 傅玮韦华, 熊怡林. 基于 RS/GIS 的泉州湾红树林湿地时空动态变化分析. 森林与环境学报, 2019,39 (2) : 143-152.

[24] 李海福. 辽河口湿地潮滩区淤蚀动态特征与生态稳定性研究 [D]. 泰安: 山东农业大学, 2020.

[25] 张玉新, 侯西勇. 国际海岸线变化研究进展综述一一基于文献计量学方法. 应用海洋学学报, 2020,39(2): 289-301.

[26] 李显东, 藏传富, 陈相龙. 淮河流域 1990-2015 年间土地利用时空变化特征及驱动机制研究. 生态科学, 2020, 39(2) : 104-113.

[27] 郭健斌, 曾维莲, 袁庆娟, 刘天平. 1978-2017 年西藏耕地面积变化态势及驱动力分析. 云南农业大学学报: 社会科学, 2020, 14(3): $100-105$.

[28] 李宏伟, 吕军, 卜坤, 魏春凤. 1976-2015 年辽河口土地利用格局变化及驱动机制研究. 中国水土保持, 2019, (12): 88-92.

[29] 张党玉, 孙志高, 陈冰冰, 路春燕, 李家兵. 近十年来福建兴化湾湿地景观格局及其驱动力分析. 福建师范大学学报: 自然科学版, $2020,36(1): 104-116$.

[30] 孙圳. 辽河口湿地翅碱蓬植被年际变化及其影响因素的相关性研究 [D]. 大连: 大连海洋大学, 2018.

[31］周金金, 张靖宜. 辽河口湿地生态环境研究综述. 环境保护与循环经济, 2019, 39(9): 50-53.

[32] 陈官滨, 刘伟男, 贾越平, 宋金金, 刘洪洋, 肖岗清, 李微. 2013-2016 年辽河口碱蓬湿地时空动态变化分析. 现代盐化工, 2018, 45(1): 64-65.

[33] 卢晓宁, 黄玥, 洪佳, 曾德裕, 杨柳青. 基于 Landsat 的黄河三角洲湿地景观时空格局演变. 中国环境科学, 2018, 38( 11)：4314-4324. 